\title{
Fishery subsidies: the interaction between science and policy
}

\author{
Yutaro Sakai $^{1}$ (D) Nobuyuki Yagi ${ }^{2} \cdot$ Ussif Rashid Sumaila ${ }^{3}$
}

Received: 3 August 2018 / Accepted: 9 March 2019 / Published online: 26 March 2019

(c) The Author(s) 2019

\begin{abstract}
Fisheries subsidies have attracted considerable attention worldwide since the 1990s. The World Trade Organization (WTO), among others, started to strengthen its disciplines in fisheries subsidies in 2001. The academic study of fisheries subsidies can play a key role in contributing to policy-making processes such as WTO negotiations by providing more accurate information on the link between subsidies and overfishing. This paper aims to review the existing academic literature and discuss the role of academic studies in the process of designing and implementing policies on fisheries subsidies. Academic studies on fishery subsides can be divided into three branches: descriptive, theoretical, and empirical. Overall, there has been significant progress in empirical studies on fishery subsidies during the last decade. While the number of studies is still limited, they generate insights that are consistent with theoretical predictions. As for potential contributions of academic studies to actual policies and sustainable management, more interaction between academic experts and policy makers is desirable.
\end{abstract}

Keywords Economic analysis $\cdot$ Fisheries subsidies $\cdot$ Sustainable fisheries $\cdot$ World Trade Organization · Overfishing

\section{Policy background on fisheries subsidies}

The issue of how to control the negative impacts of fisheries subsidies has attracted considerable attention since the 1990s among scientists, policy makers and managers worldwide. In 1992, the Food and Agriculture Organization (FAO) pointed out that providing subsidies to the fishing sector could lead to the depletion of fish stocks (FAO 1992). The World Summit on Sustainable Development in 2002 identified fisheries

Published with support by the Japan Society for the Promotion of Science (JSPS) KAKENHI Grant no. JP 262003.

Ussif Rashid Sumaila

r.sumaila@oceans.ubc.ca

Yutaro Sakai

ytr.sakai@gmail.com

Nobuyuki Yagi

yagi@fs.a.u-tokyo.ac.jp

1 School of Sustainability, Arizona State University, PO Box 875502, Tempe, AZ 85287, USA

2 Graduate School of Agricultural and Life Sciences, The University of Tokyo, Yayoi, Bunkyo, Tokyo 113-0032, Japan

3 Fisheries Economics Research Unit, Institute for the Oceans and Fisheries, the School of Public Policy and Global Affairs, University of British Columbia, Main Mall 2202, Vancouver, BC V6T 1Z4, Canada subsidies as an important issue in relation to sustainable fisheries. The United Nations Environment Program also hosted meetings and workshops on fisheries subsidies during this period (von Moltke 2012). In addition, the World Trade Organization (WTO) started work to strengthen its disciplines on fisheries subsidies in 2001. Before that, one of the main legal instruments at the disposal of the WTO was the General Agreement on Tariffs and Trade (GATT) agreed in 1947 (GATT 1947). GATT 1947 has its own disciplines focused on subsidies in general. Its article XVI provides rules on export subsidies and other forms of subsidies that could cause trade distortion. These rules were further improved during the GATT Uruguay Round of Multilateral Trade Negotiations from 1986 to 1994, and a new legal instrument, the Agreement on Subsidies and Countervailing Measures (SCM Agreement), was signed in 1994. This agreement establishes three categories of subsidies: prohibited, actionable, and non-actionable. These categories are determined based upon the trade-distortion effect of the subsidies. Potential effects of subsidies on fishery resources fall outside of the scope of the SCM Agreement.

In 2001, new negotiations of the WTO started. One of the main objectives of the negotiations was to clarify and improve WTO disciplines focused on fisheries subsidies. Members of the WTO intensively negotiated this subject and, in 2005, the WTO Hong Kong Ministerial Declaration 
(https://www.wto.org/english/thewto_e/minist_e/min05_e/ final_text_e.htm) noted that there was "broad agreement that the (Negotiation) Group should strengthen disciplines on subsidies in the fisheries sector, including through the prohibition of certain forms of fisheries subsidies that contribute to overcapacity and overfishing". There were active negotiations on fisheries subsidies for several years around 2005. However, the WTO Doha round negotiation as a whole came to an impasse in 2007, and the negotiation on fisheries subsidies also stopped. In late 2016, the negotiation group on fisheries subsidies was revitalized with the goal of achieving binding outcomes to be adopted at the WTO Ministerial Conference in 2017. This Ministerial Conference, however, did not achieve substantive outcomes.

A possible link between subsidies and overfishing was discussed during these negotiations. Participants engaged in the WTO negotiations had to tackle the problem of a lack of a common viewpoint on the effects of subsidies. Academic studies on fisheries subsidies can play a key role in these negotiations by providing more accurate information on the link between subsidies and overfishing. This paper aims to review the existing academic literature and discuss the role of academic studies in policy-making processes during the negotiation of fisheries subsidies.

\section{Three branches of academic study}

Academic studies on fishery subsides can be divided into three branches: descriptive, theoretical, and empirical. Descriptive studies determine the definition of subsidies, describe the social and political contexts under which these subsidies are funded, and estimate subsidies at local and global levels. These studies offer the foundation for subsequent theoretical and empirical analyses. Theoretical studies of subsidies started with static open access fishery models, but more recent studies include rational expectation, political economy, shared fish stocks, and international trade. They provide a number of predictions, but the general conclusion seems to be that the impact of subsidies should depend on the type of subsidies, biological characteristics of the fishery concerned, as well as the management and political systems in place. Empirical studies aim to provide systematic evidence on how subsidies affect fishery outcomes in the real world. As the data on fishery subsidies are limited, empirical studies are still scarce; however, solid advances have been made during the last decade.

\section{Descriptive studies}

The first study to provide a global estimate of fishery subsidies was a FAO report (FAO 1992). This study estimated that the annual total revenue of the global fishery at that time was in the order of US\$70 billion a year, while its total costs were around US\$ 124 billion per year. By assuming that the difference between the revenue and cost was supplemented by government subsidies, the authors concluded that global annual fisheries subsidies amounted to US\$ 54 billion a year (FAO 1992). This large estimated subsidy, together with the declining fishery resources worldwide at that time, spurred a large volume of subsequent research on the topic. Moreover, the WTO Ministerial Declaration agreed at the Doha round in 2001 that the WTO members needed to clarify and improve WTO disciplines on fisheries subsidies (Yagi 2008).

Building on the FAO's work (1992), Milazzo (1998) offered the first comprehensive analysis of fishery subsidies. He estimated that effort- and capacity-enhancing subsidies were in the range of US\$ 14-20.5 billion annually, i.e., $20-25 \%$ of the revenue of the world fishing industry. While this estimate itself is valuable, the primary contribution of Milazzo's (1998) work was to provide a detailed discussion about the various aspects of fishery subsidies. For example, recognizing that an appropriate definition of subsidies is missing in the FAO report (FAO 1992), Milazzo (1998) proposes employing the definition and procedures of the WTO SCM Agreement of 1994. Under the WTO definition, however, those subsidies that are intended to restore the health of fishery resources may not be classified as "subsidies." Thus, Milazzo (1998) treats these subsidies separately in his analysis, and finds that these so-called "environmental subsidies" account for, at most, $5 \%$ of the total subsidy.

Since Milazzo's (1998) work, the discussion about the definition of fishery subsidies has deepened (Schrank and Keithly 1999; Schrank 2003), and the history of fishery subsidies been examined (Schrank 2003). Porter (2004) makes an important contribution to this debate by highlighting that the impact of subsidies on resource stocks depends on the combination of management and biological conditions of the fishery concerned. At the same time, a number of studies have provided estimates of fishery subsidies. Flaaten and Wallis (2000) estimate that at least US\$ 4.9 billion was spent on general services for 24 Organization for Economic Cooperation and Development (OECD) countries in 1997, while about US\$ 1.4 billion was spent on revenue-enhancement and cost-reduction purposes in the same year. The AsiaPacific Economic Cooperation (APEC 2000) estimated the total subsidies in APEC countries at the time of the report, based on the information available up to April 2000, to be US\$ 12.6 billion, which consisted of US\$ 4.2 billion of beneficial subsidies and US\$ 8.4 billion of harmful subsidies for resource stocks. Building on these two estimates, Munro and Sumaila (2002) estimated that the total fishery subsidies for the North Atlantic (which includes 16 OECD and nine non-OECD countries) were in the range of US\$ 2.0-2.5 billion per year. 
The latest estimates for the global fishery subsidies are provided by Sumaila and Pauly (2006), Sumaila et al. (2010a, b), and Sumaila et al. (2016). Previously, Milazzo (1998) assumed the amount of subsidies to be zero when information about the amount of a subsidy was not available. In the three studies of Sumaila and his colleagues [Sumaila and Pauly 2006; Sumaila et al. 2010a, b; Sumaila et al. 2016] an algorithm was devised to impute these missing subsidies, arriving at more realistic estimates. These authors also provide estimates for detailed categories of subsidies, which clarify how much of the subsidies were for "good" (e.g., management and surveillance), "bad" (e.g., fuel), and "ugly" (e.g., vessel buyback) measures worldwide. Their updated estimates suggest that the global subsidies were about US\$ 35 billion (adjusted for inflation and expressed as 2009 dollars), among which fuel subsidies constituted the greatest share followed by subsidies for management.

Estimates at more national and local levels have also been carried out. Sharp and Sumaila (2009) provide detailed estimates of the amount of fisheries subsidies provided by the US government to the US fishing industry, i.e., a total of US\$ 6.4 billion from 1996 to 2004. Among these, federal and state fuel subsidies represented $44 \%$, while federal and state fishery research accounted for $40 \%$. Mallory (2016) reports that, in 2013, the Chinese central government spent RMB 40.383 billion (or US $\$ 6.5$ billion) on fisheries subsidies. Most of this amount, 94\%, was in the form of fuel subsidies. The author found that about $95 \%$ of Chinese fisheries subsidies were harmful to sustainability. Sumaila et al. (2010a, b) estimate that bottom trawl fleets operating in the high seas receive US\$125 million per year. This amounts to $25 \%$ of the total landing value of the fleet, while the profit of the fleet is normally at most $10 \%$ of the landing value, suggesting that a significant proportion of the fleet would not survive economically without these subsidies. Sumaila et al. (2014) estimate fuel subsidies for the tuna fishery in the Western and Central Pacific Ocean at US\$ 335 million and non-fuel subsidies at US\$ 1.2 billion for 2009. Based on these estimates, they find that the total resource rent of the fishery was a net negative US\$750 million. Schuhbauer et al. (2017) estimate that US $\$ 5.6$ billion were provided to small-scale fisheries (SSF) in 2009. As the total fishery subsidies were estimated to be US\$ 35 billion, this result means that SSF received only $15.6 \%$ of the total subsidies. Schuhbauer and Sumaila (2016) argue that this unequal provision of subsidies undermines the economic viability of SSF.

Another set of studies provides detailed accounts of the social and political contexts under which fishery subsidies are funded, and the consequences of these subsidies. Lindebo (2005) shows that more than 50\% of government aid to Danish fisheries during 1994-2002 was used for vessel modernization. However, Lindebo (2005) finds limited supporting evidence that catch opportunities improved for the vessels during this period. Abdallah and Sumaila (2007) describe the history of Brazilian public policy on fisheries subsidies, and discuss how fiscal incentives and rural credit policies have driven the development of fisheries as well as overfishing in recent years. Mesnil (2008) examines the consequence of government aid provided in response to three historical crises of French fisheries, and argues that the subsidies did nothing to cure the root causes of these crises. Ramírez-Rodríguez and Almendárez-Hernández (2013) show that fuel subsidies and value added tax exemptions are crucial for the economic viability of the jumbo squid fishery in the Gulf of California, Mexico.

Additionally, two studies are worth mentioning, as they shed light on new aspects of fishery subsidies. First, CullisSuzuki and Pauly (2010) argue that marine protected areas (MPAs), which are increasingly popular instruments for marine resource conservation, can be seen as a form of subsidy for fisheries. As MPAs can potentially benefit fishers in the long run, they are regarded as beneficial subsidies. Using data provided by Balmford et al. (2004), they estimate the maintenance costs of global MPAs as US\$ 870 million, which is much smaller than the estimated global subsidy of US\$ 35 billion (Sumaila et al. 2016). Second, Squires et al. (2014) make several points in defining and estimating subsidies. For example, fishing production may entail the "byproduct" of knowledge about target species as well as how to avoid bycatch. Knowing about how to avoid bycatch is likely to be a public good among fishers, which means it is undersupplied by the market. Thus, subsidies that encourage fishery production (e.g., vessel modernization) may be justified on such grounds. Another concern of Squires et al. (2014) relates to side payments made as part of environmental agreements. Although these side payments appear to be subsidies in themselves, they are a part of an agreement that can benefit all the parties involved in the agreement. If this is true, such side payments are beneficial. The examples given here indicate that estimating fishery subsidies and categorizing them as "good" or "bad" requires careful consideration.

\section{Theoretical studies}

Many fishery models have been developed since the 1950s (e.g., Clark 1990; Clark and Munro 1975) that are useful in examining the impact of subsidies. To examine the effect of cost-reduction subsidies, for instance, we modify the cost of fishing in these models. Sumaila and Pauly (2006) and Sumaila et al. (2008) use the standard Gordon-Schaefer model (Gordon 1954) to examine the impact of such subsidies. This is depicted in Fig. 1, where the total revenue (TR) and total cost (TC) of a fishery are given as a function of fishing effort $E$. Assuming the Schaefer production function, the total revenue from the fishery is bell-shaped. Similarly, assuming a constant unit cost of fishing effort, the plot of 


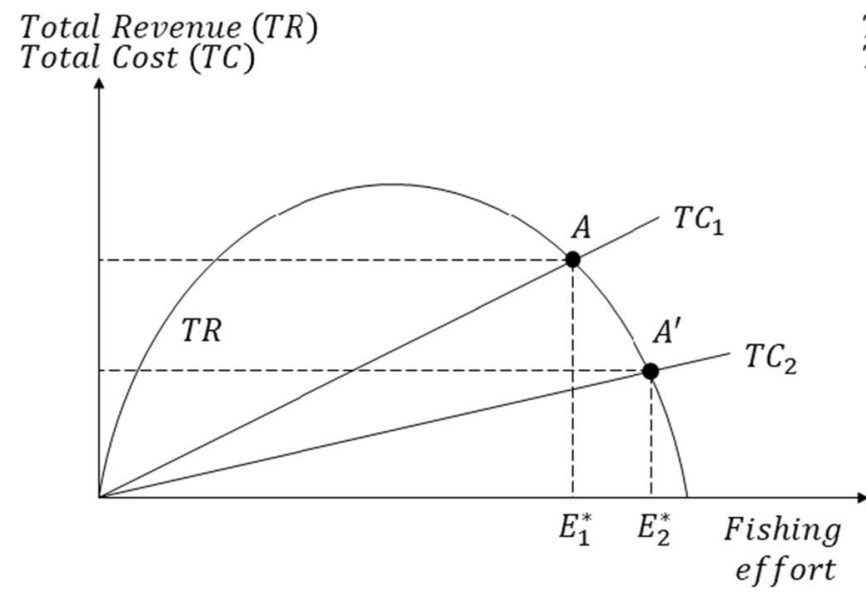

Fig. 1 Effect of cost-reducing subsidies (left panel) and price-support subsidies (right panel) in an open-access fishery. Left panel Total cost curve rotates clockwise when cost-reducing subsidies are provided. Right panel Total revenue curve shifts upward when price-support

the total cost of fishing is a straight line with an upward slope. Under open access, new vessels continue to enter the fishery until all the rents have been dissipated. As a result, bioeconomic equilibrium is achieved at point $A$, where the total revenues and total costs from fishing are equalized, resulting in zero profit from the resource. It is then easy to see how cost-reducing subsidies change the equilibrium. As the unit cost of fishing decreases, the total cost curve shifts from $\mathrm{TC}_{1}$ to $\mathrm{TC}_{2}$, and as a result, the equilibrium point moves to point $A^{\prime}$, where the fishing effort is larger but the harvests are smaller. More importantly, as larger fishing efforts correspond with lower resource stocks in equilibrium, Fig. 1 shows that cost-reducing subsidies reduce equilibrium resource stocks.

Alternatively, to examine the impact of price-support subsidies, we can adjust the price parameter in the model, as depicted in Fig. 1. As the price of fish increases due to pricesupport subsidies, the total revenue curve shifts upward to $\mathrm{TR}_{2}$, which results in an artificially inflated fishing effort, leading to lower harvests, and lower resource stocks with time.

While Fig. 1 assumes an open access fishery, most realworld fisheries are not under pure open access. Thus, one may argue that well-managed fisheries can avoid the negative impacts of the subsidies discussed above. Munro and Sumaila (2002), among others, counterargue this by building a dynamic fishery model with vessel non-malleability (Ainsworth and Sumaila 2005; Clark 1973; Martell et al. 2009). Using this model, Munro and Sumaila (2002) show that there will be the same negative impact of subsidies even when a fishery has a sole owner (or a resource manager who exercises full property rights over the resource). The reasoning for this is simple: a sole owner of the fishery whose
Total Revenue (TR)

Total Cost (TC)

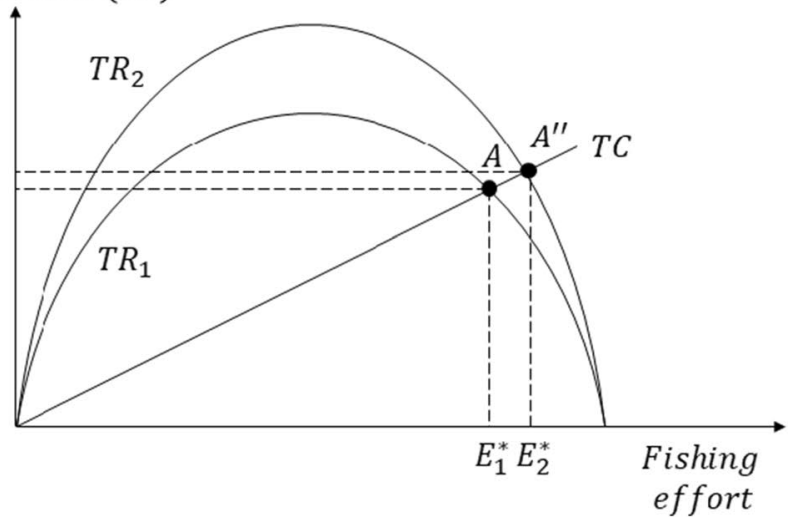

subsidies are provided. In both cases, the equilibrium fishing effort $(E)$ increases from $E 1^{*}$ to $E 2^{*}$, which in turn means the equilibrium resource stock declines

objective is to maximize the net present value of the fishery will exploit more resources when the cost of fishing is lower or the price of fish is higher due to subsidies. In fact, it is a theoretical possibility that a sole owner would choose to exhaust the fishery resource and invest the money in other sectors, if the cost of fishing became sufficiently low. Thus, Munro and Sumaila's (2002) model indicates that the negative consequence of these subsidies does not necessarily hinge on the open access nature of the fisheries.

In their model, Munro and Sumaila (2002) assume that the sole owner or the resource manager would seek to maximize the net present value of the fishery, which is the standard assumption in fisheries economics (e.g., Clark 1990). While this setting is a useful benchmark, modern real-world resource managers do not set out to only maximize the net present value of a fishery but also consider resource conservation as one of the key objectives of fisheries management. For example, Homans and Wilen (1997) provide a model of regulated open access fishery where the resource manager sets the total harvest quota to ensure stock safety (rather than to maximize the value of the fishery). When the manager sets the total harvest quota independent of fishery subsidies, cost-reducing and price-support subsidies do not, in theory, affect harvests or resources; their only impact is predicted to be on fishing effort. In practice, however, an increase of fishing effort is likely to result in the weakening of quota management systems through political process.

Poole (2000) examines such a possibility by extending the Homans and Wilen (1997) model. He allows fishers to exert political influence to affect manager's decisions on setting the total quota. Poole (2000) shows that when there is an unemployment insurance (UI) scheme (which is a type of income support) that requires a certain amount of time at 
sea for fishers to qualify, these fishers have a strong incentive to lobby to lengthen the fishing season. This will in turn increase the total harvest and potentially reduce the resource stock. Thus, his model indicates that there is scope for fishery subsidies to affect harvests and resource stocks, even if a resource manager's primary goal is to ensure resource safety. Hence, a general note of caution is appropriate here. Even if fishery managers intend to set total quotas based on the resource conservation principle, it is difficult to keep an iron-clad quota management system when there is, among other things, political pressure from powerful and influential groups in society. It is therefore still prudent to eliminate harmful subsidies even under quota management systems.

We have so far limited our discussion to cost-reducing and price-support subsidies, but there are numerous other types of subsidies. One type of subsidy, vessel buyback [classified as a "green subsidy" by Milazzo (1998)], attracts special attention in the literature. Vessel buyback programs are intended to reduce the overcapacity of fleets, which should be beneficial for the profitability of fishery and resource conservation purposes, at least at first glance. The literature shows that this premise may not necessarily be true, however. One such argument is that vessels lost from a fishery due to vessel buyback programs are likely to be the least efficient ones in the fishery. As a result, the actual fishing capacity does not decrease as much as these programs are designed to achieve. Moreover, without appropriate measures to limit fishing efforts after program implementation, the reduction in fleet capacity will be offset by new entries or input substitutions of the remaining vessels resulting in what has been described in the literature as the "seeping back in problem" (Holland et al. 1999; Weninger and McConnell 2000).

An even stronger economic argument is provided by Clark et al. $(2005,2007)$, who point out the time inconsistency problem of vessel buyback programs, where fishers will over-invest in vessels if they anticipate future vessel buyback programs. That is, if a future vessel buyback program is anticipated, it will be seen as a subsidy for investment by fishers. Thus, the impact of these programs depends on how much they are anticipated by fishers, and it seems reasonable to expect that the frequent implementation of vessel buyback programs around the world will induce existing fishers to expect similar programs in the future.

The impacts of fishery subsidies are further complicated when we consider fishers' labor-leisure choice. Jinji (2012) provides a two-sector general equilibrium model of a small open economy where fishers allocate their time to labor and leisure. Jinji (2012) shows that, under certain conditions, reductions in income support or price-support subsidies induce fishers to spend more time on fishing, which results in a decrease in resource stocks because fishers may choose to work more to offset the reduction in income. Jinji (2012) then extends the model to analyze trading equilibrium between two countries, and shows that the global subsidy reductions do not necessarily lead to resource recovery.

Some other papers focus on the interaction between countries in an attempt to explain why certain countries provide or do not reduce fishery subsidies. Ruseski (1998) builds a two-country model where there is a shared fish stock. In this model, each country has an incentive to provide effort subsidies for strategic rent-shifting purposes. Quinn and Ruseski (2008) use a similar model to show that a country with cost advantages may provide effort subsidies to domestic fleets so that it is not profitable for foreign fleets to enter the fishery. These two studies provide potential explanations for the existence of subsidies for shared fish stocks, but not for domestic stocks.

In contrast to Ruseski (1998), Bayramoglu et al. (2018) incorporate the Grossman-Helpman lobbying model in an international trade model to explain why it is difficult to remove domestic fishery subsidies. They provide three explanations for this. First, providing fishery subsidies raises the price of fish as the stock depletes, which benefits other exporting countries. Second, as the production of fishery products is bound by ecological constraints, providing subsidies does not increase harvests above certain levels, which then limits the decrease in fish prices. Third, governments can reduce subsidies while compensating for such a policy by weakening fishery regulations at the same time. These three factors may make it difficult for countries to reach an agreement to reduce domestic fishery subsidies.

Another reason why fisheries targeting shared stocks are likely to receive more subsidies stems from the classic non-cooperative, tragedy of the commons problem (Munro 1979; Sumaila and Pauly 2006), which led Sumaila (2013) to suggest that two approaches to disciplining subsidies be pursued, one for stocks that are shared and another for those that are not because the incentives faced by countries for the two types of stocks are different.

Overall, the theoretical works discussed above clarify the conditions under which different types of subsidies may have harmful effects on resource stocks. In particular, partial equilibrium models of open access fisheries indicate unambiguous negative consequences of cost-reducing or price-support subsidies. A consideration of the labor-leisure choice of fisher, however, highlights a theoretical possibility that removing such subsidies could reduce both harvests and resource stocks. Vessel buyback programs are beneficial in reducing excess capacity, but they may encourage over-investment if anticipated by fishers. In addition, the potential impact of buyback subsidies can be either positive or negative depending on the fishery management measures in place. 


\section{Empirical studies}

Three early studies focus on the impact of a specific type of subsidy, UI, on fishery outcomes in Canada. Ferris and Plourde's (1982) theory suggests that seasonal UI will only temporarily increase the income of fishers, but the gain will be dissipated through scale expansion of the fishery. Then, using time series data for the period from 1954 to 1970 , they find weak evidence that the extension of seasonal UI in 1956 increased the number of fishers in the inshore fishery in Newfoundland. Alternatively, Roy et al. (1992) and Roy (1998) use panel data of UI recipients for 1971 to 1993 to estimate the optimization condition of their model for the choice of the time spent on fishing, and then simulate counter-factual fishing time by varying UI benefits. They find that, on average, UI decreases the length of the fishing season in Newfoundland. They point out, however, that there may be some fishers who increase the time that they spend fishing to enable them to qualify for the insurance.

The first two studies that shed light on the impact of broader fishery subsidies are those of Yagi et al. (2008, 2009). Yagi et al. (2008) use a panel of 23 OECD countries during 1996-2002 to evaluate the effect of three types of subsidies (direct payments, cost-reducing transfers, general services) on seven fishery outcome variables (production, value, number of vessels, total tonnage of vessels, number of fishers, value per fisher, price). When examining the impact of subsidies at the country level, it is important to consider cultural and institutional differences across countries. For example, if some countries are more tolerant to providing subsidies and also exhibit higher demand for fishery products, we may observe a spurious positive relationship between subsidies and fishery production. To consider such possibilities, Yagi et al. (2008) included country fixed effects in their regression (whenever the Hausman test does not reject it), which controls for time-invariant unobservable heterogeneity across countries. Overall, Yagi et al.'s (2008) findings suggest that direct payments and cost-reducing transfers increase both inputs and outputs of the fishery, while general services reduce outputs of the fishery. These results are similar to those of Sumaila et al. (2013).

Similarly, Yagi et al. (2009) use time series data in Japan during 1971-2003 to examine the relationship between four types of subsidies (direct payments, cost-reducing transfers, public port infrastructure, other general services) and six fishery outcomes (production, value, value per fisher, number of fishers, price of fish, number of vessels). Based on 24 univariate error correction models, they find that only other general services and the value per fisher have a statistically significant positive relationship. Since other general services include costs of fishery management, scientific research, and other administrative activities, they argue that fishery management activities may be the driver of this positive relationship. Moreover, they argue that the result of a lack of a relationship between most subsidies and fishery outcome variables is likely due to regulatory measures in Japan that limit the impact of subsidies.

Another study, conducted in Chile by Mondaca-Schachermayer et al. (2011), examines the relationship between government funding and fishery outcomes. By looking at 32 fishing villages over the period 1996-2007, they find that the changes in landings and income are not related to the annual average funding each village received. Rather, they are related to the ecological and productive characteristics of the villages. This is somewhat surprising, given that the amount of subsidies is large (up to 59\% of the per capita income of fishers). They argue that the funding did not have any impact on fishery outcomes because most of these subsidies were aimed at improving working conditions for fishers, such as building better ports, better piers, and better storage capacity. While these types of subsidies still have the potential to lead to overfishing (by reducing the cost of fishing operations), their study sheds light on the important point that the effect of subsidies depends on what and how subsidies are spent.

Similar insight is provided by Sumaila et al. (2013), who studied the relationship between the catch loss potential and the amount of fishery subsidies for 37 small island developing states. They first use the historical catch data to estimate the maximum sustainable yield (MSY) for each fish stock, and then calculate the potential catch loss as the difference between the current catch and the MSY. They then examined the relationship between this potential catch loss and the amount of "good" and "bad" fishery subsidies by using a regression analysis. They find that bad subsidies are significantly associated with the amount of potential catch loss, while good subsidies do not have a statistically significant relationship with the potential catch loss. This result confirms what is accepted in the literature that the effect of a fishery subsidy depends on its type (Milazzo 1998; Sumaila and Pauly 2006).

Sakai (2017) provides the most recent empirical evidence for this line of research. He uses data for a panel of 23 OECD countries from 1996-2011 to examine the impact of three types of subsidies on resource stocks. Building on the theoretical predictions and empirical findings in the literature, he allows the estimated impact of subsidies to depend both on the type of subsidy and the type of fishery management. This is the first empirical study to examine the impact of subsidies on fish stocks, rather than input or output variables of a fishery. He utilizes a country-level resource index constructed by the Sea Around Us (Pauly and Zeller 2015). This resource index is created from catch data, which poses some challenges in interpreting its changes. For example, if subsidies increase fishing effort and consequently the catch, this resource index will increase in the short run. However, 
in the long run, the resource index will decrease as a result of resource degradation. Therefore, it is crucial to distinguish between the effects of subsidies in the short and long run when using this resource index. Sakai (2017) applies fixed effect models with various lag structures, and finds that the impact of subsidies on resource stocks indeed depends on the type of subsidy and management. In particular, he finds that both direct payments and cost-reducing transfers are harmful for resource stocks, while general services are beneficial. These effects are, however, may not be detected if a country uses individual quota management, as opposed to traditional input/output management. Overall, these findings are consistent with the predictions of simple partial equilibrium models.

While the studies cited above look at the impact of subsidies at macro levels, two studies examine the effect of fishery subsidies at the individual vessel level. Cordón Lagares and García Ordaz (2015) analyze the impact of government aid for Spanish purse seine vessels to leave a fishery. Their data are unique in the sense that they had access to information on whether a given vessel received aid for exiting the fishery. They find that while aid (i.e. subsidies) encourage vessels to exit the industry, the magnitude of its impact is quite small. Their analysis provides valuable empirical evidence suggesting that financial assistance to exit a fishery-which is generally perceived as a "good" subsidy—has limited effectiveness.

Duy and Flaaten (2016), in contrast, examine the effect of fuel cost support and insurance subsidies-which are generally perceived as "bad" subsidies — on the profitability of purse seine vessels in an open access fishery in Vietnam. By employing a careful identification strategy that relies on propensity score matching methods, they show that the subsidies they studied had a positive effect on the profitability of vessels, but that this effect diminished over the 2 years of their analysis. They argue that the increased profitability may have caused overfishing and resource degradation, and as a result, the profitability declined over the 2 years. Thus, Duy and Flaaten (2016) provide a potential mechanism that explains the general theoretical assertion (e.g., Milazzo 1998; Sumaila and Schuhbauer 2018) and empirical findings (e.g., Sakai 2017) that cost-reducing subsidies lead to resource degradation.

Yet another strand of research calibrates general equilibrium models to assess the feedback effects of fishery subsidies in the entire economy. Since this type of study directly includes subsidies for the profit function of vessels, the direct impact of removing these subsidies on the vessels is negative by construction. The focus of these studies is to quantify the indirect effects of such a policy. For example, Carvalho et al. (2011) examine how reduction in fishery subsidies affects the entire economy of the Azores, Portugal. Using a dynamic computable general equilibrium model, they show that reducing fishery subsidies has negative impacts on fishing sectors, while it has positive impacts on the economy as a whole, except for exports and employment. They argue that the reduction in fishery subsidies increases the disposable income for households through tax cuts (as the government keeps the budget balance), which then allows households to increase their consumption. It is notable that in these models reducing fishery subsidies would increase the unemployment rate, despite the overall increase in the welfare of the economy. This is likely to be a short-run result. As Carvalho et al.'s (2011) model does not consider fishery resource dynamics, the reduced subsidies only result in a higher unemployment rate. In the long run, however, the fishery resource should recover and the employment rate in the region may rise.

García-Cutrín et al. (2017) build a general equilibrium model that includes resource stock dynamics, which affects the productivity of heterogeneous vessels. They calibrate the model to industrial shrimp fisheries in Mexico and show that the benefit of removing subsidies is much larger when stock recovery is considered in the simulation. Moreover, they find that the income and consumption inequality in the economy will shrink when stock recovery occurs. This suggests that the social cost of reducing fishery subsidies is much smaller than one would think within the partial equilibrium framework.

\section{Future challenges}

Overall, the literature on fishery subsidies shows that significant progress has been made in the last three decades. Descriptive and theoretical studies clarify under what conditions various subsidies are beneficial or harmful. While the number of empirical studies is still limited, they generate insights that are consistent with theoretical predictions by simple partial equilibrium models. Given that an increasing amount of data on fishery subsidies is becoming available, there is scope for more studies.

In particular, the fisheries support estimate (FSE) database recently developed by the OECD seems to provide a potential avenue for future research (OECD 2017). The FSE database replaces the government financial transfer (GFT) database, and it provides more detailed subsidy data for OECD countries. For example, the FSE database includes an independent category for the provision of infrastructure, the effect of which is controversial as previous studies could not examine its impact due to data limitation. Another strength of the FSE database is that the People's Republic of China - the country with the largest total amount of fishery subsidies-is included. As such, the scope of the database has increased, even though it still does not include data for many of the world's coastal countries. 
One drawback, however, of the FSE database is that it only goes back to 2009. Researchers may be able to manually append the FSE and GFT (which started in 1996) databases, but they must make sure that the data series are consistent across databases. In addition, quality is always of concern for both GFT and FSE data, as they are selfreported. As such, it is important for empirical researchers to use other sources of data (e.g., academic databases) and various techniques to mitigate the shortcomings of the FSE database. For example, country fixed effect estimation may mitigate the concern that some countries systematically under-report their subsidies. Alternatively, SEs that allow heteroscedasticity may be useful if some countries report their subsidies data with high variances. Researchers should also conduct estimations using various subsamples of countries to ensure that the main result is not affected by a group of countries with low quality data.

Another potential direction for empirical studies is to analyze the impact of subsidies at the fishery level. Existing studies are conducted at the regional level or at the vessel level due to data limitation. However, from a policy perspective, it is more useful to examine which subsidies are effective/ineffective in which fisheries, as the relevant management unit is a fishery. Thus, a fishery-level analysis will yield more useful insights for fishery management. It is also desirable that future empirical studies employ careful identification strategies, as in Duy and Flaaten (2016) and Sakai (2017). To evaluate the impact of subsidies, we need to know counterfactual outcomes, e.g., what would have happened without the subsidies? As fishery subsidies are not distributed randomly to fishers, it is challenging to construct a control group of fishers that can be used to assess a counter-factual outcome. In this regard, both fixed effect models and propensity score matching methods are useful, if not perfect, tools to provide us with such control groups.

As for possible contributions of academic studies to society, more interactions between academic experts (such as economists and scientists) and policy makers (such as diplomats and politicians) are desirable. Under the current situation, the participation of economists and other experts on fishery science is limited to a handful of large delegations like those of the European Union, Japan, Norway, and USA. Most members of groups negotiating fisheries subsidies at the WTO are diplomats and they are usually not aware of the progress that has been made in studies in this field. More outreach toward delegation members from developing countries needs to be considered to strengthen the bond between science and the implications of fisheries subsidies worldwide.

Open Access This article is distributed under the terms of the Creative Commons Attribution 4.0 International License (http://creativeco mmons.org/licenses/by/4.0/), which permits unrestricted use, distribution, and reproduction in any medium, provided you give appropriate credit to the original author(s) and the source, provide a link to the Creative Commons license, and indicate if changes were made.

\section{References}

Abdallah PR, Sumaila UR (2007) An historical account of Brazilian public policy on fisheries subsidies. Mar Policy 31(4):444-450

Ainsworth CH, Sumaila UR (2005) Intergenerational valuation of fisheries resources can justify long-term conservation: a case study in Atlantic cod (Gadus morhua). Can J Fish Aquat Sci 62(5):1104-1110

APEC (2000) Study into the nature and extent of subsidies in the fisheries sector of APEC members economies. PricewaterhouseCooopers report no. CTI 07/99T, pp 1-228

Balmford A, Gravestock P, Hockley N, McClean CJ, Roberts CM (2004) The worldwide costs of marine protected areas. Proc Natl Acad Sci 101(26):9694-9697

Bayramoglu B, Copeland BR, Jacques J (2018) Trade and fisheries subsidies. J Int Econ 112:13-32

Carvalho N, Rege S, Fortuna M, Isidro E, Edwards-Jones G (2011) Estimating the impacts of eliminating fisheries subsidies on the small island economy of the Azores. Ecol Econ 70(10):1822-1830

Clark CW (1973) The economics of overexploitation. Science 181(4100):630-634

Clark CW (1990) Mathematical bioeconomics. Wiley, New York

Clark CW, Munro G (1975) The economics of fishing and modern capital theory: a simplified approach. J Environ Econ Manage 2(2):92-106

Clark WC, Munro RG, Sumaila RU (2005) Subsidies, buybacks, and sustainable fisheries. J Environ Econ Manage 50:47-58

Clark CW, Munro GR, Sumaila UR (2007) Buyback subsidies, the time consistency problem, and the ITQ alternative. Land Econ 83(1):50-58

Cordón Lagares E, García Ordaz F (2015) Factors influencing the decision to leave a fishery and the effects of fishery subsidies: the case of the Spanish purse seine fishery. Ocean Coast Manage 116:248-256

Cullis-Suzuki S, Pauly D (2010) Marine protected area costs as "beneficial" fisheries subsidies: a global evaluation. Coast Manage 38(2):113-121

Duy NN, Flaaten O (2016) Profitability effects and fishery subsidies: average treatment effects based on propensity scores. Mar Resour Econ 31(4):373-402

FAO (1992) Marine fisheries and the Law of the Sea: a decade of change. FAO fisheries and aquaculture technical paper 853, FAO

Ferris JS, Plourde C (1982) Labour mobility, seasonal unemployment insurance, and the Newfoundland inshore fishery. Can J Econ 15(3):426-441

Flaaten O, Wallis P (2000) Government financial transfers to fishing industries in OECD. In: IIFET 2000 proceedings

García-cutrín J, Prellezo R, Sempere J (2017) The social cost of fishery subsidy reforms. Mar Policy 83:236-242

Gordon SH (1954) The economic theory of a common-property resource: the fishery. J Polit Econ 62(2):124-142

Holland D, Gudmundsson E, Gates J (1999) Do fishing vessel buyback programs work: a survey of the evidence. Mar Policy 23(1):47-69

Homans FR, Wilen JE (1997) A model of regulated open access resource use. J Environ Econ Manage 32(1):1-21

Jinji N (2012) Fisheries subsidies and management in open economies. Mar Resour Econ 27:25-41

Lindebo E (2005) Role of subsidies in EU fleet capacity management. Mar Resour Econ 20(4):445-466 
Mallory TG (2016) Fisheries subsidies in China: quantitative and qualitative assessment of policy coherence and effectiveness. Mar Policy 68:74-82

Martell SJ, Walters C, Sumaila UR (2009) Industry-funded fishing license reduction good for both profits and conservation. Fish Fish 10(1):1-12

Mesnil B (2008) Public-aided crises in the French fishing sector. Ocean Coast Manage 51(10):689-700

Milazzo M (1998) Subsidies in world fisheries: a reexamination. World Bank, Washington, DC, p 23

Mondaca-Schachermayer IC, Aburto J, Cundill G, Lancellotti D, Tapia C, Stotz W (2011) An empirical analysis of the social and ecological outcomes of state subsidies for small-scale fisheries: a case study from Chile. Ecol Soc 16(3):17

Munro GR (1979) The optimal management of transboundary renewable resources. Can J Econ 12(3):355-376

Munro GR, Sumaila UR (2002) The impact of subsidies upon fisheries management and sustainability: the case of the North Atlantic. Fish Fish 3(4):233-250

OECD (2017) Support to fisheries: levels and impacts. OECD food, agriculture and fisheries papers no. 103. OECD, Paris

Pauly D, Zeller D (2016) Toward a comprehensive estimate of global marine fisheries catches. In: Pauly D, Zeller D (eds) Global Atlas of Marine Fisheries: A critical appraisal of catches and ecosystem impacts. Island Press, Washington D.C., pp 171-181

Poole E (2000) Income subsidies and incentives to overfish. In: IIFET 2000 proceedings

Porter G (2004) Analyzing the resource impact of fisheries subsidies: a matrix approach. United Nations Development Programme, Geneva

Quinn J, Ruseski G (2008) Effort subsidies and entry deterrence in transboundary fisheries. Nat Resour Model 14(3):369-389

Ramírez-Rodríguez M, Almendárez-Hernández LC (2013) Subsidies in the jumbo squid fishery in the Gulf of California, Mexico. Mar Policy 40:117-123

Roy N (1998) Fishing behavior and the length of the fishing season. Mar Resour Econ 13(3):197-213

Roy N, Tsoa E, Schrank WE, Mazany L (1992) Unemployment insurance and the length of the fishing season. In: IIFET 1992 proceedings

Ruseski G (1998) International fish wars: the strategic roles for fleet licensing and effort subsidies. J Environ Econ Manage 36(1):70-88

Sakai Y (2017) Subsidies, fisheries management, and stock depletion. Land Econ 93(1):165-178

Schrank WE (2003) Introducing fisheries subsidies. Fisheries technical paper 437. FAO

Schrank WE, Keithly RW (1999) The concept of subsidies. Mar Resour Econ 14:151-164

Schuhbauer A, Sumaila UR (2016) Economic viability and small-scale fisheries-a review. Ecol Econ 124:69-75

Schuhbauer A, Chuenpagdee R, Cheung WWL, Greer K, Sumaila UR (2017) How subsidies affect the economic viability of small-scale fisheries. Mar Policy 82:114-121
Sharp R, Sumaila RU (2009) Quantification of US marine fisheries subsidies. N Am J Fish Manage 29:18-32

Squires D, Clarke R, Chan V (2014) Subsidies, public goods, and external benefits in fisheries. Mar Policy 45:222-227

Sumaila UR (2013) How to make progress in disciplining overfishing subsidies. ICES J Mar Sci 70(2):251-258

Sumaila UR, Pauly D (2006) Catching more bait: a bottom-up reestimation of global fisheries subsidies. Fish Centre Res Rep 14(6): 114

Sumaila UR, Schuhbauer A (2018) A simple application of bioeconomics to fisheries subsidies. In: Juan Carlos Seijo JGS (ed) Advances in fisheries bioeconomics theory and policy. Routledge, London, pp 115-129

Sumaila UR, Teh L, Watson R, Tyedmers P, Pauly D (2008) Fuel price increase, subsidies, overcapacity, and resource sustainability. ICES J Mar Sci 65(6):832-840

Sumaila UR, Khan A, Teh L, Watson R, Tyedmers P, Pauly D (2010a) Subsidies to high seas bottom trawl fleets and the sustainability of deep-sea demersal fish stocks. Mar Policy 34(3):495-497

Sumaila UR, Khan SA, Dyck JA, Watson R, Munro G, Tydemers P, Pauly D (2010b) A bottom-up re-estimation of global fisheries subsidies. J Bioecon 12:201-225

Sumaila UR, Dyck A, Cheung WWL (2013) Fisheries subsidies and potential catch loss in SIDS exclusive economic zones: food security implications. Environ Dev Econ 18:427-439

Sumaila UR, Dyck A, Baske A (2014) Subsidies to tuna fisheries in the Western Central Pacific Ocean. Mar Policy 43:288-294

Sumaila UR, Lam V, Le Manach F, Swartz W, Pauly D (2016) Global fisheries subsidies: an updated estimate. Mar Policy 69:189-193

von Moltke A (2012) Fisheries subsidies, sustainable development and the WTO. Fisheries subsidies, sustainable development and the WTO. Routledge, London

Weninger Q, McConnell KE (2000) Buyback programs in commercial fisheries: effciency versus transfers. Can J Econ 33(2):394-412

Yagi N (2008) Negotiation on fisheries subsidies at WTO Doha round. Nippon Suisan Gakkaishi 74(5):776-783 (in Japanese with English abstract)

Yagi N, Senda Y, Ariji M (2008) Panel data analyses to examine effects of subsidies to fishery productions in OECD countries. Fish Sci 74:1229-1234

Yagi N, Ariji M, Senda Y (2009) A time-series data analysis to examine effects of subsidies to fishery productions in Japan. Fish Sci 75:3-11

Publisher's Note Springer Nature remains neutral with regard to jurisdictional claims in published maps and institutional affiliations. 